\title{
Adaptation of young people from foreign countries based on the study of spiritual and moral subjects
}

\author{
Tamara Olenich ${ }^{1 *}$, Anatoly Koryakin ${ }^{1}$, and Diana Ovcharenko ${ }^{2}$ \\ ${ }^{1}$ Don State Technical University, 1, Gagarin square, 344003, Rostov-on-Don, Russia \\ ${ }^{2}$ Sunday School of the Holy Trinity Church of Taganrog, 344/1, Chekhova Str., 347900, \\ Taganrog, Russia
}

\begin{abstract}
The analysis of the adaptation of the students' youth from foreign countries within Russian society and the educational environment is presented in the current research. The authors study the problem of adaptation based on the case of the Don State Technical university which is providing activities on increasing the number of foreign students. Logically this university's politics lead to the engagement of the students from many foreign countries and the gradual formation of the multicultural and multi-confessional community within the campus. Despite the engagement of a large number of the representatives of different cultures the university, namely, the Orthodox culture and theology department has established the number of innovative educational methods and educational techniques which contribute to the adaptation of the foreign youth into Russian society. These new methods are based on the establishment of spiritual and moral subjects which were integrated into the educational process. The results of the cycle of the research activities have confirmed that these methods can be effectively used for the adaptation of the foreign students within Russian society.
\end{abstract}

\section{Introduction}

This study explores how the youth from foreign countries is adapting to the new societies and new cultures based on the example of the activities carried out by the Don State Technical University (DSTU). The topicality of the research is rather urgent because the number of international students in the Russian universities is increasing each year so to keep on increasing the number of international students in the Russian HEIs, it is necessary to research experience and best practices of adaptation and new educational technologies which can make the educational process more comfortable and understandable for the international students [1]. If we consider the case of the Don State Technical University, the priority area of work with the foreign youth is to work out and to apply new approaches and methods of education process based on the study of spiritual and moral values to integrate the youth from foreign countries to the local community and to foster interosculation of different cultures.

\footnotetext{
*Corresponding author: tamara1970@inbox.ru
} 
One of the pressing problems which sometimes may appear for the teaching staff is presence of misinformation - "social myths" - among foreign students who come to study in Russia, about the country, history and culture, people and traditions. In most cases foreign student come to Russia with the positive attitude and without any prejudice. Therefore, teachers of educational institutions now are faced with two tasks: to continue presenting the history and traditions of Russia, its national cultural values, achievements of science, literature, etc.; and to dispel the anti-Russian myths in the student's minds, instilled at home country with the help of the mass media [2].

In practical activities aimed at the adaptation of foreign students, today not only university services and student associations - traditional participants in adaptation activities also take government authorities, cultural institutions, as well as non-profit organizations. In addition to individual independent projects implemented by various institutions, today there are more and more examples of increasing cooperation. Practice shows that events organized in an interdisciplinary and intersectoral format are often more effective. In this respect, the case of the Don State Technical University and organization of work with the foreign students in this university is of current interest.

In many universities in recent years, significant changes have been taking place associated with the adjustment of both educational programs and the teaching methodology. DSTU has opened many new areas of training - media communications, veterinary medicine, wine-making technology, etc.

Annually, about 2000 foreign students come to start studying at the university. Within the framework of international cooperation, interaction with 60 countries is being implemented. For example, the university and Shandong Transport University have created a joint educational project "Don Institute SHTU-DSTU" [3].

The university played an important role in the fact that the city of Yantai became the sister city of Rostov-on-Don. As part of an agreement between the board of the Yantai High and New Technologies Zone and DSTU, the HEI has opened a Russian-Chinese technology transfer centre. Besides, the university has prepared a unique book for DSTU students on the methods of studying the Chinese language. Also, it is planned to develop a Russian language textbook for Chinese students.

DSTU and the Spanish Embassy signed a memorandum on the dissemination of the study of the Spanish language. Based on the flagship university there is a department of the Spanish language, in three educational institutions of the city, programs of the in-depth study of Spanish have been introduced.

Being universal, the university works in a variety of areas. At the same time, despite all the innovations in the educational process, the HEI has retained the machine-building and agricultural directions. The university continues to train qualified professionals for foundry, metal forming and other traditional areas.

According to the engagement of such big numbers of foreign students, the problem of adaptation and integration of the youth is relevant for the university. Of course, this scientific issue is relevant not only for this universities. The revival of interest in new pedagogical methods and communicative strategies for foreign students is associated with the socioeconomic characteristics of the modern society, the search and revival of stable and humanistic spiritual guidelines to facilitate the adaptation of the foreign youth in national societies of the different countries, especially in the EU [4].

Foreign youth who came to study in Russian HEIs, namely DSTU, find themselves in a very difficult situation. Student life becomes a serious task for them because they need to master studying at a higher educational institution and to prepare for their future profession, but also to adapt to a completely new sociocultural space [5]. 
The difficulties that a foreign student experiences especially acutely in the first year of stay in a new country can be grouped as follows:

- psychophysiological difficulties associated with personality reorganization, acquaintance with new surroundings, psycho-emotional stress, climate change, etc.;

- educational and cognitive difficulties associated, first of all, with insufficient language training, overcoming differences in education systems; adaptation to new requirements and knowledge control system;

- sociocultural difficulties associated with the development of the new social and cultural space of the university; overcoming the language barrier in solving communication problems.

Cultural traditions and regional characteristics play an important role in the formation of adaptation skills among foreign students [6].

Low knowledge about the peculiarities of Russian society and traditions, norms of etiquette and culture may cause conflicts between foreign students and the local population. The acculturation process takes a long time.

For the successful socio-cultural adaptation of a foreign student, it is necessary for the student:

- to master the language sufficiently to effectively function to stay in a host society;

- mastered the standards of behaviour, values and norms of the host society;

- to be able to communicate and interact with representatives of the society;

- to be able to fully participate in social and cultural life of a new society;

- to be satisfied with their position in a new environment;

- to be in a normal psychological state [7].

Integration of foreign students is both a process and a result of the inclusion of a foreign citizen in the system of social, legal and cultural relations of the host society as its full rightful and permanent member. Integration is often associated with obtaining by a foreign citizen the right to a temporary or permanent residence in the country, as well as obtaining citizenship of the host country [8].

Adaptation and integration are linked in stages. Successfully adapted to socio-cultural, economic and legal surroundings of the host society, a foreign student can get the opportunity to gradually integrate into the local community, becoming its full member.

The novelty of this research is that based on the pedagogical experiment and permanent surveys for the first time it was convinced that studying the cultural code of Russian society in a multi-confessional environment through spiritual and moral subjects is an effective way of adaptation for foreign students and it can minimize risks of conflict even in the multicultural community which has formed in the DSTU.

\section{Methodology}

The research is aimed to examine acclimatization of foreigners through the study of spiritual and moral subjects - culture-communication in the Don State Technical University based on the results of the cycle of research activities: educational experiment (2014 - 2017), survey (2017) and survey (2020).

The case study method was used to investigate how foreign youth can be changed under the influence of the study of spiritual and moral courses. In more detail, the correlation between integration and acclimatization of the foreign youth based on educational experiments and monitoring of the adaptation during and after the experiment was considered in the research to test the hypothesis that innovative educational tools - in our case, the study of spiritual and moral disciplines in the new forms - can facilitate adaptation for international students and create conditions for dialogue between cultures and their mutual exchange. 


\section{The educational experiment in the Don State Technical University}

The Orthodox culture and theology department operates at the Don State Technical University. Moreover, DSTU is the only university in which such a department is open. In all courses, students study the history and culture of Orthodoxy. The university management has collected first- and second-year students and for two semesters they study disciplines related to world religions on an optional basis.

During three years, 2014-2017, on the initiative of the management of the Don State Technical University, the pedagogical experiment was conducted at the HEI aimed at studying the readiness of young people to take subjects of a traditional spiritual and moral orientation [9]. More than 1000 students aged 18 to 35 years were involved in the experiment.

The course of the experiment: during the reconnaissance research, a readiness to study subjects of a spiritual and moral orientation was revealed at all 1st and 2nd courses of the DSTU since 2014. One of the peculiarities of the experiment was that the methodological guidance on such subjects as "Fundamentals of Morality" and "Fundamentals of Orthodox Culture" was supplemented with a block of practical exercises - conversations in the Church of the Holy Martyr Tatiana at the DSTU. All conversations (4 of them) were conducted strictly at the request of the students themselves. At the end of the course, students were asked to leave appropriate feedback on the Theologos.ru website. At the request of students, excursions to Orthodox Temples and museum complexes were organized not only in the Rostov region but also to the other regions, to the capital.

At the end of the experiment, which lasted 3 years, the students were offered to share their feedbacks about the pedagogical experiment "The Path to the Temple". To do it they carry on the survey which purpose was to determine and describe the attitude of DSTU students to the subjects studied "Fundamentals of morality" and "Fundamentals of Orthodox culture" and the Russian Orthodox Church.

The analysis of the respondents' answers, showed that, in their opinion, the Orthodox values are one of the important elements of the development of modern Russia. The Orthodox Church forms the spiritual and value basis of society and supports the functioning of such values as:

-spirituality;

-patriotism as love for people;

- statehood as trust in a strong ("autocratic") state;

- striving for freedom and independence;

- striving for justice and equality in serving the Motherland and the state;

-collectivism and communality;

- spiritual asceticism.

During the implementation of the project, as a result, the following quantitative results were obtained: among more than 1000 surveyed students - 38\% consider themselves to be believers, $62 \%$ do not. $23 \%$ are sure that spiritual and moral education is necessary and useful knowledge, $38 \%$ believe that it is a process of a lifetime, the foundations of which are laid, including during the student years. $30 \%$ think that this is a useless pastime because a person is an intelligent creature and can find answers to many questions himself. $70 \%$ of the respondents answered in the affirmative to the question: "Did the conversation with the priest help you to sort out your internal issues? Did it influence your attitude to faith?" Also, 95\% of the participants in the excursion and educational trips were satisfied with the excursions, meetings, visits to temples and monasteries. Thus, we can state the fact that the pedagogical experiment "Path to the Temple" was completed successfully, the hypotheses of the research were fully confirmed. The practical stage was a form of introducing the best forms and methods of spiritual and moral education and upbringing of DSTU students. 
The main conclusions that can be drawn from the results of the study are as follows: for Russia, the Western path is not suitable, since the archetypes of Orthodox culture have formed completely different moral norms and traditions. Patriarch Kirill notes that since the time of Rousseau the idea of the sufficiency of state protection of the rights and freedoms of man and citizen has been entrenched in Western thinking, and the individual will choose what is good and useful for their life.

After the experiment in 2017, the authors additionally measured the results of the abovementioned educational activities and revealed the following facts via an additional small survey (120 students who studied at the faculty).

1. Students of the Don State Technical University support the efforts of the Russian Orthodox Church to participate in spiritual education together with state educational institutions;

2. At the Don State Technical University, Orthodox believers are the dominant social group according to the survey "The influence of traditional values on the social and spiritual life of youth" (2017) conducted by the Department for Youth Affairs and Missionary Service of the Rostov Diocese. Within the survey one hundred thirty students of the Don State Technical University who attended the lecture courses "Fundamentals of Morality" and "Fundamentals of Orthodox Culture" took part in a cycle of conversations with the Rector of St. Tatiana the Great Martyr and the head of the Department for Youth Affairs and Missionary Service of the Rostov Diocese, Priest Mikhail Gaponenko, were interviewed.

The results of the survey showed that 79 of the students consider themselves believers, 111 were baptized in the Orthodox faith, and 71 students point that the implementation of the abovementioned courses helped to understand spiritual and moral issues better and to adapt better to the Russian student's community in which they live and study.

\section{The attitude of young people of the Rostov region to the Russian Orthodox Church and believers in the context of their support for traditional cultural values: survey results}

In 2017 the university Orthodox culture and theology department carried out and presented the results of a sociological survey conducted by Don State Technical University, entitled "The attitude of young people of the Rostov region to the Russian Orthodox Church and believers in the context of their support for traditional cultural values" [10].

The study involved more than 1000 students of the leading universities of the region. The survey polled respondents aged 18 to 35 . For quantitative characteristics in the study used a survey method that is carried out by a formalized form.

This study is the geographical coverage of the territory of the Rostov region which is the area of the multicultural traditions.

The hypothesis of the sociologic study was the following: Orthodox Church seeks to engage in moral education, together with the secular institutions of education and culture; the Russian Orthodox believers have become the dominant social group in the region; Russian Orthodox Church is considered by the Russian youth, including foreigners, which live in the region, as a respected social institution.

National composition of the respondent's families is various. $71 \%$ - Russian, $18 \%-$ Ukrainian, 5\% - Ingush, by 2\% Mariyts, Tatars and Kabardinians.

Among the interviewees were 82\% Russian, 9\% Ukrainian, 5\% Ingush, 2\% Mariyts and 2\% Kabardinians. Distribution of respondents by nationality is presented on Figure 1. 


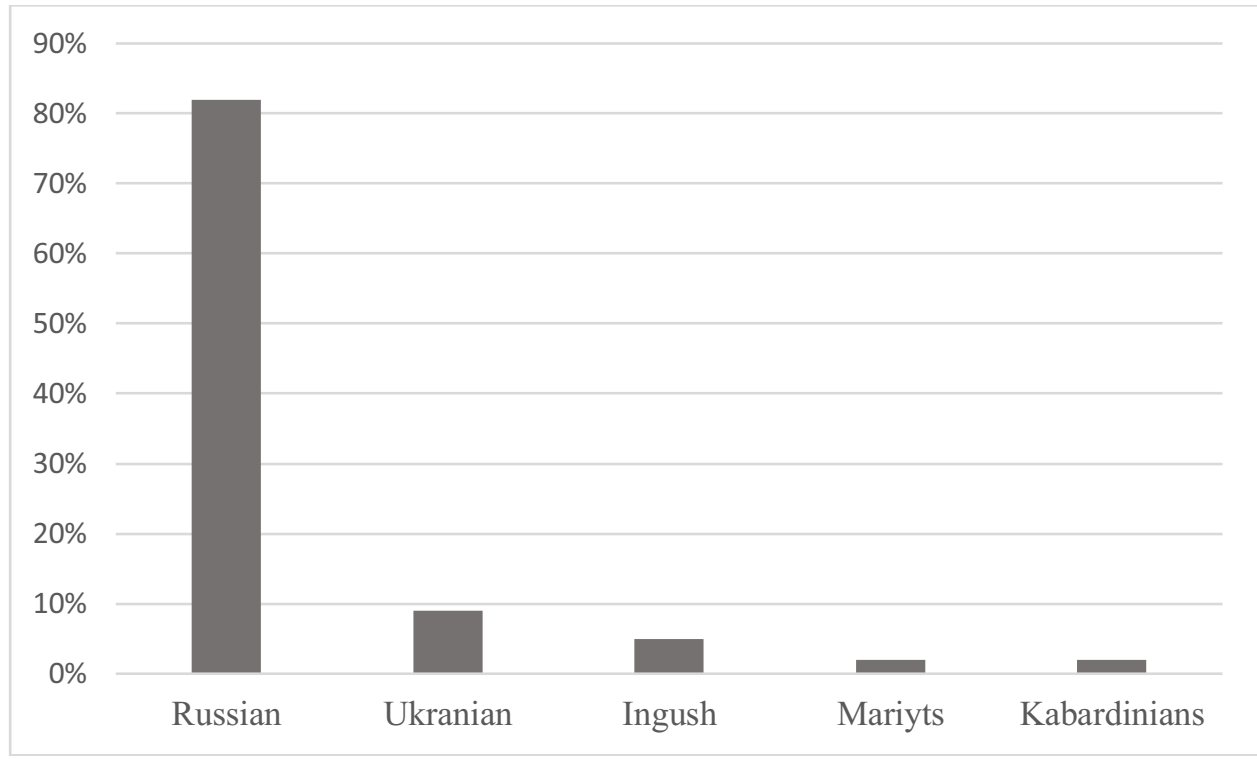

Fig.1. Distribution of respondents by nationality

All respondents $-80 \%$ of young people call themselves Orthodox and Christians. 9\% identified themselves as Muslims and to other faiths or freethinking ranked 11\% of young people.

$73 \%$ of respondents believe Orthodoxy to be the basis of Russian culture, $13 \%$ of young people have not been able to answer this question, and only $14 \%$ disagree with this opinion (Fig.2).

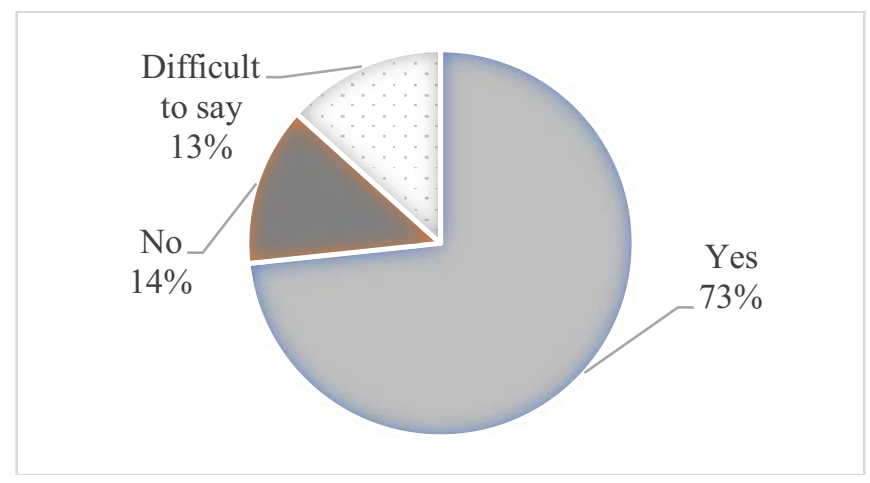

Fig.2. Distribution of respondents by their attitude to the social role of Orthodoxy.

The study also showed the need of the young people to have a more profound study of the fundamentals of Orthodox culture, including in the school and university programs. For example, more than $65 \%$ of respondents believe that the Russian Orthodox Church should increase the number of Sundays and parochial schools. $56 \%$ of respondents consider it necessary to study the fundamentals of Orthodox culture in schools.

In the course of sociological research hypotheses were confirmed:

1. In the Rostov Region community supports the efforts of the Russian Orthodox Church to engage in moral education, together with the secular institutions of education and culture. The role of the Russian Orthodox Church in moral education in our country is evaluated highly. 
2. In South of Russia (North Caucasus), Orthodox believers have become the dominant social group in promoting the positive spiritual values.

3. Once in the Soviet Union the tradition of the Russian Orthodox Church was artificially interrupted and its social status has been restored today.

Familiarizing youth to the cultural heritage of its people is also very popular among young people (70\% support this type of activity) as an activity of the Russian Orthodox Church. In addition to the need for cultural education, $70 \%$ of young people specified a need for a moral assessment of the phenomena of modern life and maintaining a high level of morality in society as one of the main functions of the Russian Orthodox Church.

The participation of the Russian Orthodox Church in promoting spiritual and moral values within the family also was appreciated by young people: the majority $(65 \%)$ believe that the Church has to pay attention to this issue, while $56 \%$ of respondents consider it necessary to educate children and youth in the Orthodox tradition in educational institutions. These results lead to the conclusion that "Russian Orthodox Church should actively pursue spiritual guidance of youth life" through the promotion of traditional values.

\section{The influence of innovative pedagogical methods of spiritual education: results of the survey}

Survey 'The effectiveness and pedagogical potential of religious excursions as a pedagogical innovation' (2020). The hypothesis of the survey was to check whether excursions on religious topics are the elements of a living pedagogical process that gives the process of acquiring knowledge in the field of religious culture the opportunity to integrate into real-life [11].

The key question was posed to 100 students: "Do you think it was possible to replace a lecture as the study method while studying the spiritual subjects?" (Table 1. Implementation of new methods into educational process).

Table 1. Implementation of new methods into educational process.

\begin{tabular}{|l|c|}
\hline $\begin{array}{l}\text { The question: } \\
\text { "Do you think it was possible to replace a lecture as } \\
\text { the study method while studying the spiritual } \\
\text { subjects?" }\end{array}$ & Number of students, \% \\
\hline $\begin{array}{l}\text { In no case, some things cannot be simply retold, they } \\
\text { need to be felt" }\end{array}$ & $38(38 \%)$ \\
\hline $\begin{array}{l}\text { "It is possible, but it is still to the detriment because a } \\
\text { person should be able to study the spiritual sphere in } \\
\text { practice" }\end{array}$ & $24(24 \%)$ \\
\hline "Yes, I do not see any special obstacles in this process" & $24(24 \%)$ \\
\hline "Other" & $14(14 \%)$ \\
\hline
\end{tabular}

It is interesting to note that the voices were divided into four options and option "A" became the first in popularity: "In no case, some things cannot be simply retold, they need to be felt." (38\% of respondents chose it, $14 \%$ of whom considered themselves to be non-believers). The second place was shared by options "B" and "C", which sound like this: "It is possible, but it is still to the detriment because a person should be able to study the spiritual sphere in practice" (the answer was chosen by $24 \%$ of the respondents, including $10 \%$ of non-believers) and "Yes, I do not see any special obstacles in this process" (24\%). Another 14\% chose the "Other" option, where they noted that such excursions should be longer, given in a separate block.

The next question of the survey was aimed at finding out what exactly was significant for the respondents during the excursion to the temple. To the question: "What is most important, in your opinion, in this form of the lesson", the following answers were indicated: 
- communication and the opportunity to ask questions;

- content and accessible presentation of the material;

- the fertile atmosphere of the temple;

- the personality of the priest;

- information about the opportunities and activities of youth in the Church;

- other.

These answers fully confirm the assumption that the presentation of material in the form of excursions on religious topics is the most effective way of spiritual and moral education of young people.

The effectiveness of the excursion as an educational process depends on many components and this is the competence of the guide, the presence of the guide's personal spiritual experience in church life, and a well-prepared travel program, and the level of comfort of movement and the mood of the team, the weather and many other factors [12]. However, the main factor, undoubtedly, is the religious sites themselves - monasteries, temples and, most importantly, a positive example of the worldview, competence, professionalism, spiritual core of those representatives of the Church with whom the students meet and communicate during the excursion.

There is no doubt that it is necessary to include religious excursions in the work of educational institutions. Students and pupils can:

- to develop curiosity towards the study of religious experience, moral and ethical issues;

- to observe a complete picture on the topic indicated in the excursion, while not only listening and absorbing but also contemplating, getting practical experience in solving spiritual and moral problems.

At the end of the excursions, the students repeatedly noted a change in their attitude to the world around them, in relations to the team. The trips themselves, the hours spent together, the discussion on the way back of the controversial and significant spiritual development issues, make it possible to form a team spirit, to get rid of fussiness, selfishness, rethink values, and take a fresh look at the world around them.

In the professional activity of an ordinary teacher, this trend is quite new, and today there is a need to increase the practice of conducting this kind of pedagogical innovations. Because this type of educational activity turned out to be an affordable and effective means of educating the young generation, which is in demand among different categories of pupils and students due to the availability of presentation of material that affects the consciousness and personality formation [13].

The educational experiment was successfully implemented at the university and the educational institutions of Rostov-on-Don, and it was positively assessed by the teachers and students. Young people, including international students, have the opportunity of informal communication with a clergyman, get acquainted with the traditional criteria of morality in Christianity, about God - how Orthodox Christians see and know Him, about faith as an instrument of obtaining true knowledge. Besides, within the framework of the project, youth representatives got the opportunity to learn about the cultural and spiritual history of the local region, to reconsider their point of view on the spiritual guidelines and reality of modern life, etc.

Thus, excursions on religious topics can be used not only as a form of training and education but also as one of the means of the initial awakening of interest in the topic of religion and morality in general. 


\section{The adaptation of the foreign youth in the Don State Technical University}

While implementing the educational experiment in the DSTU, we have compared the youth in Russia and the EU, and according to the researches the foreign youth feel at home in Europe and strive to openly occupy the European intellectual and social space, but they are to remain faithful to their domestic values [14]. If we consider Muslim seekers of a university degree, antiMuslim prejudice has developed as a result of stereotype generating processes in the last couple of decades [15].

The Russian youth is more tolerant of the other cultures and, in our opinion, it is connected with tolerant spiritual values based on the revival of traditions of Orthodox culture. There is a trend towards the acclimatization of foreigners through the study of spiritual and moral subjects - culture-communication.

The evidence is based on the case of the Don State Technical University which is developing three international projects aimed to foster intercultural communication of the youth and to deepen knowledge in foreign cultures (e.g. "HE and VET alliance establishment according to Bologna Principals implementation via VET teachers' capacity building").

The educational initiatives of the Russian HEIs in promoting international cultural exchange 2020-2025 are aimed to increase the competitiveness of Russian education on the international market of educational services new ideas and forms of communication with the representatives of the different cultures. Among them, there are new communicative strategies: "Positive Interest" Strategy (aimed to deepen knowledge on other cultures) and "National Treasure" Strategy (aimed to preserve national values).

The DSTU successfully participates in the programs of the European Commission TEMPUS IV and Erasmus +. In 2018-2019, the flagship university submitted 12 applications for Key Action 2 "Cooperation to develop the potential of higher education" and seven applications for Jean Monnet. Three of them were supported by the European Commission and oriented to the study in the multicultural environment.

Investigating the process of adaptation of the foreign students in the Don State Technical University, it must be highlighted that the university is developing a model of adaptation for foreign students to Russian culture and traditions, which is based on the formation of tolerance and respect for the carriers of different cultures and religions through the implementation of spiritual and moral subjects and study of the culture, language and traditions of Russia.

According to surveys that were conducted among international students in 2017 at DSTU, international students $(84.6 \%$ of the respondents) - consider one of the critical tools for adaptation to Russian society to study subjects of spiritual and moral orientation and the foundations of Orthodox culture.

Among the students surveyed are representatives of Vietnam, Africa, China, Turkmenistan, Syria. Of the 46 respondents, Orthodox believers are 4\%, 42\% are Buddhism (China), African cults $-35 \%$, Protestantism 3\%, Catholicism 4\% and others [16].

The surveyed students note an unusual form of conducting classes: conversations with teachers, introduction to the cultures of the international students, and only then introduction to the traditions of Russian culture and writing an essay. Also, in the opinion of the students, visits to temples and conversations with priests became an exciting form of work.

\section{Conclusions}

The study conducted by us verified that presentation of spiritual values as an educational tool could reduce the level of potential radicalization of young people and create conditions for increasing the cultural, moral and educational potential of the youth. 
New communicative strategies and projects foster international cultural exchange based on spiritual values instilled in youth during the educational process through innovative educational tools like museum visits, camber sessions or excursions on religious topics. Such innovative educational forms like visits to the local museum, excursions to the local religious places of interest can be considered as a variant of the religious tourism as well as they promote to the best understanding between the representatives of different cultures as well as to contribute to the soft adaptation of the foreign youth [17]. In the present paper we have considered the example of DSTU. Therefore, the case of the Orthodox culture was taken as an example. But the complex of methods suggested by the Orthodox culture and theology department can be applied in any university of the world as well as within any culture code and mentality to contribute to mutual understanding and tolerance.

The numbers obtained within the surveys have shown that with the help of innovative pedagogical technologies values the youth in developing their worldview and internal system of values.

Based on the analysis of on the results of the cycle of research activities: educational experiment (2014-2017), survey (2017) and survey (2020), it is logical to assert that the hypotheses put forward in the research process was confirmed: the innovative educational tools - the study of spiritual and moral disciplines in the new forms - can facilitate adaptation for foreign students and create conditions for dialogue between different cultures and their mutual exchange.

An essential practical result is also the fact that the introduction of spiritual and moral disciplines established by the Orthodox culture and theology department in the new forms potentially contributes to:

- familiarizing foreign students with Orthodox culture and traditions;

- increasing interest in Orthodox culture and traditions;

- attracting a large number of foreign students who are still in search of the right path, thanks to the support of the clergy in an informal setting;

- an increase in the number of giving up pernicious habits, thanks to an integrated approach to the personality which is integrated into spiritual and moral disciplines;

- the formation of an Orthodox worldview and a healthy lifestyle among the residents of the Don Territory, the establishment of new social contacts, as well as joint leisure and active recreation.

Based on the results of the educational experiment and surveys, also we can conclude that one of the most important conditions for the successful socio-cultural adaptation of the foreign students to the new environment is the organization of interpersonal interaction and mutual understanding between teachers and students, students and representatives of different cultures within the group, faculty and the university. It is highly recommended to take the following activities:

- to treat all religions with respect and tolerance without exceptions;

- to have a more sensitive approach dealing with international students;

- to develop programs for adaptation for the international students which can include language courses, spiritual and moral subjects concerning the culture and traditions of the Orthodox culture and traditions;

- to implement the study of the spiritual culture of Russia, the foundations of Orthodox culture and to use best practices worked out at the Don State Technical University to facilitate the accumulation of international students into Russian society (essays, visits to the museums and churches, special courses).

\section{References}


1. I. Luchinkina, N. Senchenko, E3S Web Conf., 210 (2020) doi: https://doi.org/10.1051/e3sconf/202021017018

2. S. Garanina, V. Matveenko, I. Shabaeva, MHS:IA, 2, 19-25 (2017) doi: 10.7442/20719620-2017-9-2-19-25

3. B. Meskhi, et al 2020 IOP Conf. Ser.: Mater. Sci. Eng., 1001, 012100 (2020) doi:10.1088/1757-899X/1001/1/012100

4. S. Genner, D. Süss, The International Encyclopedia of Media Effects, 4-14 (2017) doi: 10.1002/9781118783764.wbieme0138

5. O. Shipunova, I. Berezovskaya, 6, 35-45 (2020) doi:10.32603/2412-8562-2020-6-3-35-45

6. A. Legkonogikh, G. Mezinova, S. Popova and C. Karimova, SHS Web Conf., 70 (2019) doi: https://doi.org/10.1051/shsconf/20197002007.

7. O. Orzhel, K. Tryma, ISJUL, 2(10), 70-86 (2021) doi: 10.31874/2520-6702-2020-10-270-86

8. V. Rodionova, L. Shvatchkina, G. Mogilevskaya, V. Bilovus and V. Ivashova, E3S Web Conf., 210 (2020) doi: https://doi.org/10.1051/e3sconf/202021014005

9. I. Grekov, O. Orlenko, SHS Web of Conferences, 70 (2019) doi: 10.1051/shsconf/2019700500205002

10. T. Olenich, A. Mekushkin, N. Mamchits and N. Ugrekhelidze, E3S Web Conf., 175 (2020) doi: 10.1051/e3sconf/202017515032

11. T. Olenich, Yu. Maslova, T. Klimenko, V. Zakharova, A. Astakhova, K. Vodenko. E., 107, 5045-5048 (2019)

12. K. Szafraniec, PSR, 2(198), 167-187 (2017)

13. J. Zalewska, PSR, 1(205), 65-84 (2019) doi: 10.26412/psr205.05

14. K. Tryma, ISJUL, 2 (8), 102-107 (2019) doi:10.31874/2520-6702-2019-8-2-102-107

15. S. Williams, Iran: The Essential Guide to Customs \& Culture, Great Britain, Kuperard, 115-116 (2016)

16. B.Ch. Meskhi, N. Yu. Sklyarova, A.V. Blagin, T.V. Shkil T.V., and I.V. Mardasova, HSS, 1, 163-170 (2017)

17. T. Olenich, A. Mekushkin, O. Shestopalova-Todarchuk, Global Development of Religious Tourism. IGI Global. Pennsylvania. USA, 83-97 (2020) doi: 10.4018/978-1-7998-57921.ch006/ 